THE NEW POL I C E S C I N C E 
Critical Perspectives on Crime and Law

Edited by Markus D. Dubber 
E D I T E D B Y MARKUS D. DUBB E R A N D M A R A N A VA L E R D

\section{The New Police Science}

The Police Power in Domestic and International Governance

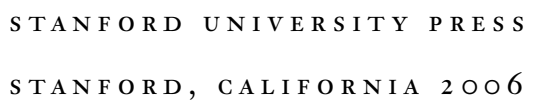


Stanford University Press

Stanford, California

(C) 2006 by the Board of Trustees of the Leland Stanford Junior University. All rights reserved.

No part of this book may be reproduced or transmitted in any form or by any means, electronic or mechanical, including photocopying and recording, or in any information storage or retrieval system without the prior written permission of Stanford University Press.

Printed in the United States of America on acid-free, archival-quality paper

Library of Congress Cataloging-in-Publication Data

The new police science : the police power in domestic and international governance / Edited by Markus D. Dubber and Mariana Valverde.

p. cm.-(Critical perspectives on crime and law) Includes bibliographical references and index.

ISBN-I 3: 978-O-8047-5392-o (cloth : alk. paper)

ISBN-IO: O-8047-5392-X (cloth : alk. paper)

I. Police power-Philosophy. 2. Police-

Philosophy. 3. International police-

Philosophy. I. Dubber, Markus

Dirk. II. Valverde, Mariana, dateK3220.N49 2007

$34^{\prime}$.041 8 - dc22 2006022052

Typeset by G\&S Book Services in Io/14 Janson 